\title{
Kendali Arah pada Brain Computer Interface Berbasis Steady State Visual Evoked Potentials
}

\author{
Jaler Sekar Maji*1 ${ }^{1}$, Catur Atmaji ${ }^{2}$ \\ ${ }^{1}$ Prodi Elektronika dan Instrumentasi, DIKE, FMIPA UGM, Yogyakarta, Indonesia \\ ${ }^{2}$ Departemen Ilmu Komputer dan Elektronika, FMIPA UGM, Yogyakarta, Indonesia \\ e-mail: *1.jaler.sekar.m@mail.ugm.ac.id, ${ }^{2}$ catur_atmaji@ugm.ac.id
}

\begin{abstract}
Abstrak
Berbagai penelitian mengenai sistem Brain Computer Interface (BCI) dengan sinyal Electroencephalogram (EEG) berbasis Steady State Visual Evoked Potentials (SSVEP) telah dikembangkan sebagai implementasi BCI terkait dengan kendali arah, namun masih memiliki berbagai kekurangan di antaranya adalah durasi klasifikasi cenderung lama, kanal elektroda yang digunakan terlalu banyak serta peletakan kanal elektroda khusus di area tertentu saja. Penelitian ini dikembangkan sistem BCI berbasis SSVEP dengan durasi klasifikasi satu detik, empat kanal aktif serta peletakan kanal elektroda sesuai The International 10-20 System. Stimulus yang digunakan berupa objek berwarna merah dengan frekuensi kedip $11 \mathrm{~Hz}$ yang merepresentasikan kelas kendali arah kiri, objek berwarna biru dengan frekuensi kedip $13 \mathrm{~Hz}$ yang merepresentasikan kelas kendali arah kanan serta latar berwarna putih yang merepresentasikan kelas relaks. Filter bank pada delapan jangkauan frekuensi $(11 \mathrm{~Hz}, 22 \mathrm{~Hz}$, $33 \mathrm{~Hz}, 13 \mathrm{~Hz}, 26 \mathrm{~Hz}, 39 \mathrm{~Hz}, 12-29 \mathrm{~Hz}$ dan 30-50 Hz) dilanjutkan dengan Root Mean Square (RMS) digunakan dalam ekstraksi ciri untuk setiap satu detik datanya. Klasifikasi dengan Jaringan Syaraf Tiruan (JST) dan 5-Fold Cross Validation digunakan untuk mengetahui performa dari sistem yang dikembangkan. Sistem BCI yang telah dikembangkan menghasilkan akurasi sebesar 78,20\% dengan True Positive Rate (TPR) 86,00\% dan False Discovery Rate (FDR) 23,21\%.
\end{abstract}

Kata kunci-EEG, BCI, SSVEP, JST, Kendali Arah

\begin{abstract}
Various studies regarding to Steady State Visual Evoked Potentials (SSVEP) based Brain Computer Interface (BCI) system with Electroencephalogram (EEG) signal has developed as BCI implementation on directional control, however lackness found on those studies which are long time on classification duration, to many electrode channels used and the electrode channels located on special area. This study we developed the SSVEP based BCI system with one second classification duration, four active channels used and electrode channels located based on The International 10-20 System. Stimulus used are red colored object with $11 \mathrm{~Hz}$ frequency rate represents as left directional control class, blue colored object with $13 \mathrm{~Hz}$ frequency rate represents as right directional control class and white colored background represents as relax class. Filter bank with eight frequency range $(11 \mathrm{~Hz}, 22 \mathrm{~Hz}, 33$ $\mathrm{Hz}, 13 \mathrm{~Hz}, 26 \mathrm{~Hz}, 39 \mathrm{~Hz}, 12-29 \mathrm{~Hz}$ dan 30-50 Hz) followed by Root Mean Square (RMS) used as feature extraction for every second of data. Artificial Neural Network (ANN) classification and 5-Fold Cross Validation are used to knowing the performance of the developed system. Developed BCI system resulted accuracy 78,20\% with True Positive Rate (TPR) 86,00\% and False Discovery Rate (FDR) 23,21\%.
\end{abstract}

Keywords-EEG, BCI, SSVEP, ANN, Directional Control 


\section{PENDAHULUAN}

EEG (Electroencephalogram) berawal dari penelitian perekaman aktivitas otak dalam bentuk sinyal elektrik dengan menggunakan galvanometer dan meletakkan dua elektrode pada kulit kepala manusia manusia oleh Richard Caton pada tahun 1876. Sejak saat itu nama EEG dikenal dari konsep Electro (berkaitan dengan aktivitas elektrik dari otak), Encephalo (sinyal yang datang dari otak) dan gram (grafik). Berbagai penelitian EEG dilakukan untuk berbagai tujuan seperti mempelajari hal-hal yang berhubungan dengan otak manusia seperti epilepsi, keberadaan sinyal EEG, hubungan antara aktivitas mental dengan perubahan sinyal EEG dan mempelajari sinyal EEG pada kondisi tidur [1].

Seiring dengan berkembangnya teknologi komputer, aktivitas-aktivitas otak dapat direkam sekaligus diterjemahkan menjadi sinyal kontrol yang dapat diaplikasikan, hal ini disebut dengan BCI (Brain Computer Interface). BCI sendiri sudah dikenal sejak tahun 1964 oleh Dr. Grey Walter dengan melakukan penelitian dimana elektroda telah dipasangkan pada area otak pasien. Pasien diinstruksikan untuk menekan tombol dan hasil rekaman ini sudah langsung ditampilkan pada slide proyektor oleh Dr. Walter [2].

Sinyal EEG yang dihasilkan oleh BCI bisa berasal dari berbagai rangsangan atau stimulus seperti aktifitas otak ketika pengguna fokus pada gambar di komputer (Visual Evoked Potential), suara (Audio) dan imajinasi (Motor Imagery). Berbagai rangsangan ini selanjutnya diproses lebih lanjut secara umumnya melalui sistem klasifikasi hingga keluarannya dapat digunakan sebagai sinyal kontrol atau komunikasi sebagai implementasi BCI. Berdasar banyaknya luaran BCI dapat menghasilkan luaran sebanyak dua kelas untuk dua kendali seperti pada permainan BCI bergerak ke kiri dan ke kanan; tiga kendali berupa maju, mundur dan berhenti; empat kendali yaitu move control (utara, selatan, barat dan timur) [3-5]. Salah satu contoh aplikasi BCI untuk game adalah BCI BrainRunners yang menggunakan tiga kendali yaitu SPEED, JUMP dan ROLL yang dikendalikan melalui Motor Imagery [4].

Sumber sinyal BCI salah satunya dapat dihasilkan dengan melakukan fokus pada gambar tertentu (Visual), seperti yang telah diterapkan pada kuis matematika sederhana dengan opsi jawaban yang berwarna sehingga subjek dapat menjawab kuis tersebut dengan fokus pada salah satu opsi jawaban yang memiliki warna yang berbeda dan kanal yang digunakan adalah AF3, AF4, F3, F4, F7, F8, O1 dan O2 dengan jendela waktu satu detik untuk klasifikasi dua kelas menghasilkan ratarata akurasi sebesar 75,98\% [6]. Visualisasi objek tak berwarna dengan latar belakang warna menghasilkan ciri yang lebih baik dengan akurasi sebesar 63,98\% disbanding dengan visualisasi objek tak berwarna tanpa latar belakang warna dengan akurasi sebesar 56,45\% [7]. Lampu LED dengan variasi kedipan yang berbeda $(7 \mathrm{~Hz}, 9 \mathrm{~Hz}, 11 \mathrm{~Hz}$ dan $15 \mathrm{~Hz}$ ) digunakan sebagai stimulus atau biasa disebut dengan sistem BCI berbasis SSVEP (Steady State Visual Evoked Potential) dengan implementasi berupa kendali gerak robot humanoid dan kanal yang digunakan adalah $\mathrm{O} 1$ dan $\mathrm{O} 2$ dengan jendela waktu lima detik untuk klasifikasi empat kelas menghasilkan rata-rata akurasi sebesar 75\% [8]. Implementasi online pada sistem BCI berbasis SSVEP dengan menghasilkan akurasi $80 \%$ untuk empat kelas klasifikasi yang menggunakan jendela waktu 4 detik data [9]. Akurasi yang lebih tinggi yaitu sebesar 84,08 $\pm 15,60 \%$ pada implementasi online BCI berbasis SSVEP, akan tetapi elektroda khusus di area yang tidak berambut saja [10].

Berbagai penelitian yang sudah ada masih memiliki kekurangan, diantaranya durasi klasifikasi yang digunakan cenderung lama, kanal elektroda yang digunakan terlalu banyak serta peletakan kanal elektroda khusus di area tertentu saja. Dengan demikian, pengembangan sistem BCI berbasis SSVEP dengan durasi klasifikasi lebih singkat, penggunaan kanal elektroda yang tidak terlalu banyak dan peletakan kanal elektroda sesuai dengan standar yang ada perlu dilakukan. 


\subsection{Akuisisi Data}

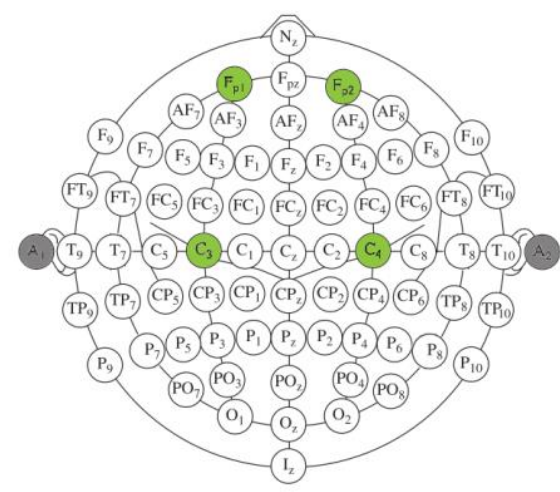

Gambar 1 Penempatan elektroda sesuai dengan Sistem Internasional 10-20 [1]

Proses perekaman data berupa sinyal EEG dilakukan dengan piranti perekam sinyal EEG berupa OpenBCI Ganglion dengan frekuensi sampling $200 \mathrm{~Hz}$. Piranti ini terpasang di helm Ultracortex Mark IV yang juga tempat meletakkannya elektroda. Peletakan kanal elektroda sesuai dengan Sistem Internasional 10-20 seperti yang ditunjukkan pada

Gambar 1. Digunakan 6 kanal elektroda yaitu 4 kanal elektroda aktif yang terdiri dari kanal FP1, FP2, C3 dan C4 sebagai perekam aktifitas otak yang berhubungan dengan perhatiain logikal, pengendalian diri, integrasi sensorimotor kanan dan integrasi sensori motor kiri serta 2 kanal elektroda yang dipasangkan pada telinga kanan dan telinga kiri sebagai referensi dan ground.

\subsection{Prosedur Eksperimen}

Perekaman data sinyal EEG terdapat dua sesi. Masing-masing sesi terdapat tiga buah stimulus yang merupakan perwakilan dari kelas kendali arah kiri, kelas relaks dan kelas kendali arah kanan. Stimulus tersebut dirancang sesuai dengan SSVEP, kelas kendali arah kiri diberikan frekuensi kedipan $11 \mathrm{~Hz}$ didukung pemberian warna merah, dan kelas kendali arah kanan diberikan frekuensi kedipan $13 \mathrm{~Hz}$ didukung pemberian warna biru, sedangkan kelas relaks adalah latar berwarna putih pada antarmuka pernangkat lunak perekaman data. Subjek penelitian diharuskan untuk fokus pada objek stimulus tersebut sesuai yang sesuai dengan skema pewaktuan pada

Gambar 2.

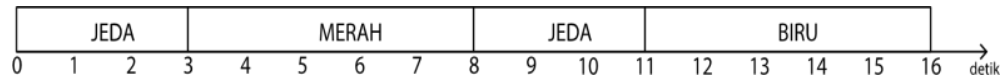

Gambar 2 Skema pewaktuan untuk pengambilan data

Antarmuka yang digunakan pada penelitian ini ditunjukkan pada Gambar 3. 


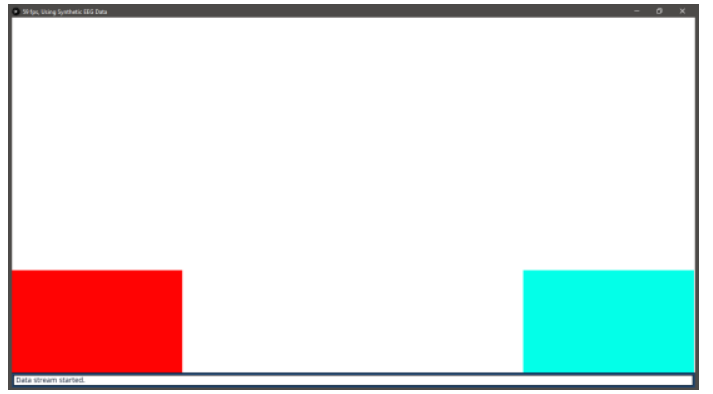

Gambar 3 Tampilan antarmuka pengambilan data

Prosedur pengambilan data pada sesi pertama adalah kedua stimulus serta latar dimunculkan secara bergantian dengan urutan tiga detik awal merupakan persiapan yang ditampilkan latar saja (kelas relaks), dilanjutkan dengan durasi lima detik oleh stimulus kelas kendali arah kiri yang ditampilkan di pojok kiri bawah layar, kemudian tiga detik oleh kelas relaks dibersamai dengan hilangnya stimulus kendali arah kiri, dan diakhiri dengan stimulus kendali arah kanan di pojok kanan bawah layar selama lima detik. Proses tersebut diulangi sebanyak dua kali untuk sekali perekaman data. Gambar 4 menunjukkan langkah pemunculan stimulus.

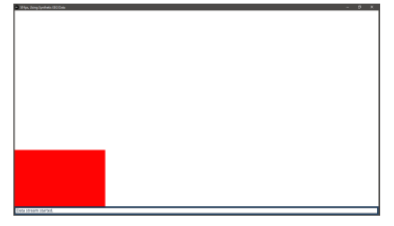

(a)

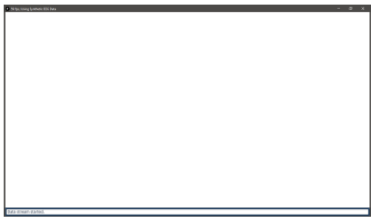

(b)

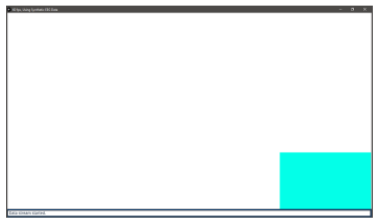

(c)

Gambar 4 Tampilan antarmuka data sesi pertama: (a) stimulus kendali arah kiri ; (b) stimulus relaks; (c) stimulus kendali arah kanan

Prosedur pengambilan data sesi kedua adalah semua stimulus dimunculkan hingga berakhirnya sesi pengambilan data. Subjek penelitian diinstruksikan untuk fokus pada stimulus tertentu sesuai dengan skema pewaktuan yang akan diberikan instruksi audio. Tampilan antarmuka pada sesi kedua ditunjukkan pada Gambar 5.

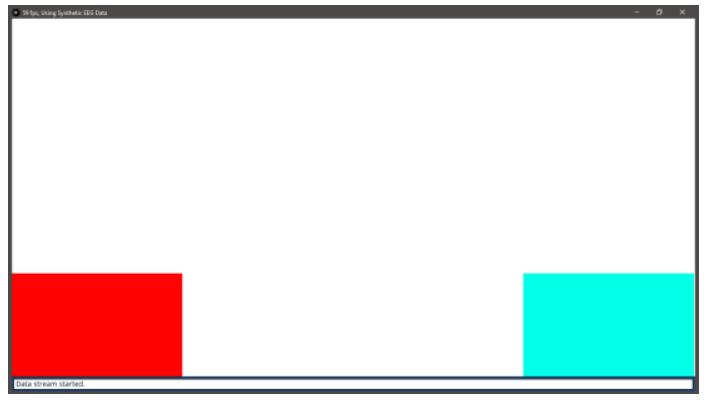

Gambar 5 Tampilan antarmuka pengambilan data sesi kedua

IJEIS Vol. 10, No. 2, October 2020 : 155 - 166 
Antarmuka pengambilan data ditampilkan dalam sebuah layar LED dengan durasi 32" dengan jarak $75 \mathrm{~cm}$ dari mata subjek penelitian. Subjek penelitian duduk dalam sebuah ruangan yang tenang dan dalam kondisi relaks atau nyaman.

\subsection{Pra Pengolahan Data}

Sinyal mentah EEG yang diperoleh terdapat sinyal gangguan atau noise yang berasal dari piranti perekaman data yang digunakan yaitu sebesar $50 \mathrm{~Hz}$ yang merupakan interferensi kelistrikan dari Ganglion Board. Proses berikutnya akan diamati frekuensi pada jangkauan frekuensi $1-50 \mathrm{~Hz}$ sehingga pra pengolahan data digunakan tapis notch $50 \mathrm{~Hz}$ dan tapis lolos tengah $1-50 \mathrm{~Hz}$ dengan tapis digital butterworth order-2.

\subsection{Ekstraksi Ciri}

Sistem BCI berbasis SSVEP memiliki kecenderungan pada frekuensi harmonik dari frekuensi kedipan [8]. Frekuensi harmonik pada penelitian ini adalah frekuensi harmonik untuk $11 \mathrm{~Hz}$ yaitu $11 \mathrm{~Hz}, 22 \mathrm{~Hz}, 33 \mathrm{~Hz}$ dan $13 \mathrm{~Hz}$ yaitu $13 \mathrm{~Hz}, 26 \mathrm{~Hz}, 39 \mathrm{~Hz}$. Penelitian yang ada juga menunjukkan bahwa kecenderungan frekuensi tidak tepat pada frekuensi harmonik tersebut melainkan lebih kecil atau lebih besar dari angka harmonik tersebut, maka pada penelitian ini digunakan jangkauan frekuensi gelombang beta (12-29 Hz) dan gelombang gamma (30-50 Hz). Sehingga filter bank digunakan dalam proses ekstraksi ciri dengan menggunakan tapis lolos tengah pada ke-delapan jangkauan frekuensi sesuai pada Gambar 6.

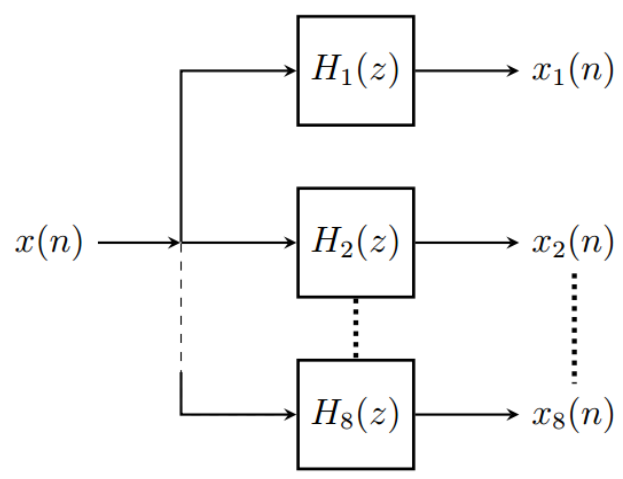

Gambar 6 Filter bank

Jangkauan frekuensi dengan tapis lolos tengah filter bank tersebut adalah sebagai berikut.
1. $H_{l}(z): 10-12 \mathrm{~Hz}$.
5. $H_{5}(z): 25-27 \mathrm{~Hz}$.
2. $H_{2}(z): 21-23 \mathrm{~Hz}$.
6. $H_{6}(z): 38-40 \mathrm{~Hz}$.
3. $H_{3}(z): 32-34 \mathrm{~Hz}$.
7. $H_{7}(z): 12-29 \mathrm{~Hz}$.
4. $H_{4}(z): 12-14 \mathrm{~Hz}$.
8. $H_{8}(z): 30-50 \mathrm{~Hz}$

Ciri yang digunakan adalah ciri pada ranah waktu, dimana setiap ciri merupakan nilai RMS yang berasal dari potongan satu detik data pada masing-masing sinyal hasil filter bank. Dengan demikian setiap satu detik data untuk setiap kanalnya dihasilkan delapan buah ciri RMS. Persamaan yang digunakan untuk menghitung nilai RMS ditunjukkan pada persamaan (1).

$$
x_{R M S}=\sqrt{\frac{1}{N} \sum_{i=1}^{N} x_{i}^{2}}
$$

$x_{R M S}$ merupakan nilai RMS dengan $N$ adalah banyaknya data yang meliputi data dari detik ke-0 hingga data detik ke-1 dengan $x_{i}$ merupakan nilai dari data tersebut. 
Dengan demikian terdapat 32 ciri yaitu delapan nilai ciri pada setiap kanal aktif (empat kanal aktif) sesuai pada

Gambar 7.

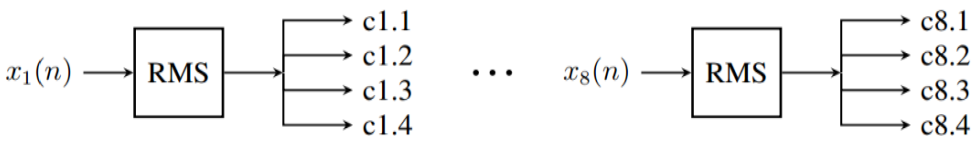

Gambar 7 Ekstraksi ciri RMS

\subsection{Klasifikasi}

Data yang telah diolah dan diperoleh cirinya, selanjutnya akan dilakukan tahap klasifikasi dimana data-data ciri dari setiap potongan data tadi diproses untuk menjadi luaran akhir pada sistem klasifikasi yaitu kendali arah. Tahapan ini akan digunakan Jaringan Syaraf Tiruan (JST) dengan lapisan masukan adalah ciri, fungsi aktivasi sigmoid bipolar dan fungsi identitas yang pada akhirnya menghasilkan luaran berupa kendali arah. Proses pelatihan arsitektur dari JST menggunakan metode backpropagation dengan acuan error sebelumnya.

Arsitektur JST yang digunakan terdiri dari satu lapisan masukan, satu lapisan tersembunyi dan satu lapisan luaran. Lapisan masukan terdiri dari 32 ciri yang merupakan node masukan. Lapisan luaran terdiri dari 3 node. Sedangkan pada lapisan tersembunyi jumlah node ditentukan berdasarkan jumlah node masukan dan luaran yaitu jumlah node tersembunyi adalah $2 / 3$ dari jumlah node masukan kemudian ditambahkan dengan jumlah node luaran [11]. Dengan demikian jumlah node tersembunyi adalah $2 / 3(32)+3 \approx 24$.

Proses pelatihan jaringan JST terdapat lapisan luaran berupa target pelatihan yaitu luaran yang diharapkan sesuai pada Tabel 1.

Tabel 1 Target keluaran pada klasifikasi JST

\begin{tabular}{|c|c|c|}
\hline No. & Jenis kendali arah & Target Luaran JST \\
\hline 1. & Kiri & 100 \\
2. & Relaks & 010 \\
3. & Kanan & 001 \\
\hline
\end{tabular}

Hasil dari klasifikasi JST tersebut masih berupa nilai yang mendekati target yang diberikan, jika ditargetkan 1 maka nilainya akan mendekati 1 dan jika ditargetkan 0 maka nilainya akan mendekati 0 . Proses perhitungan akurasi dengan Confusion Matrix harus diketahui terlebih dahulu jenis kendali arah yang diperoleh setiap dilakukannya klasifikasi dengan JST, maka dari itu nilai-nilai luaran hasil dari JST tadi perlu diubah menjadi 1 dan 0 agar sesuai pada Tabel 1. Pengubahan nilai ini dilakukan dengan membandingkan nilai satu sama lain pada tiga nilai luaran dari klasifikasi sesuai pada diagram alir pada Gambar 8.

IJEIS Vol. 10, No. 2, October 2020 : 155 - 166 


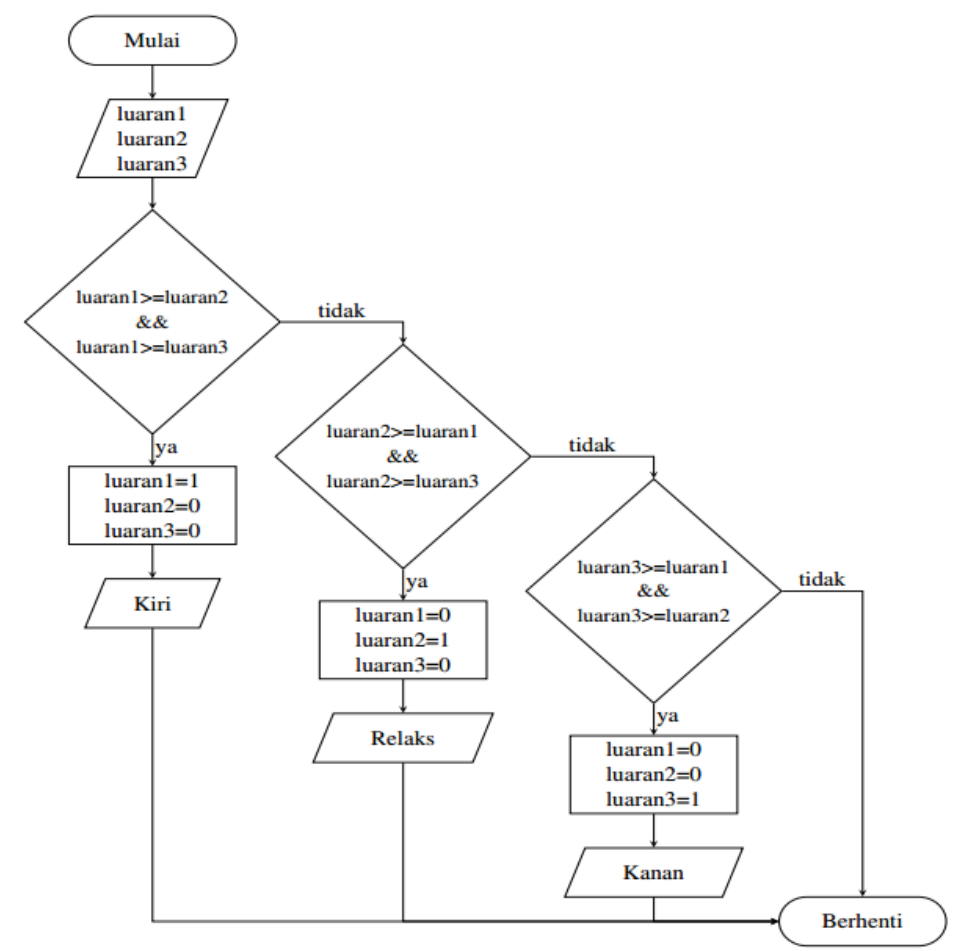

Gambar 8 Diagram Alir Blok Pembanding Kendali Arah

Nilai yang terbesar akan dijadikan nilai 1, sedangkan yang lainnya akan dijadikan nilai 0. Dengan demikian setiap dijalankannya klasifikasi dengan JST dapat diketahui jenis kendali arahnya yang akan digunakan pada perhitungan akurasi dengan Confusion Matrix baik untuk pengujian jaringan JST maupun untuk pengujian sistem yang akan dibuat

\subsection{Pengujian Sistem}

Sistem BCI dengan JST yang telah dibuat diperlukan pengujian, sehingga sistem tersebut dapat teruji kevalidannya. Metode pengujian yang digunakan adalah K-Fold Cross Validation, dengan nilai K adalah 5 sehingga menjadi 5-Fold Cross Validation. Porsi data latih yang digunakan sebesar $80 \%$ dan data uji yang digunakan sebesar $20 \%$, diulang sebanyak lima kali dengan data latih dan data uji yang bergantian sesuai pada Gambar 9.

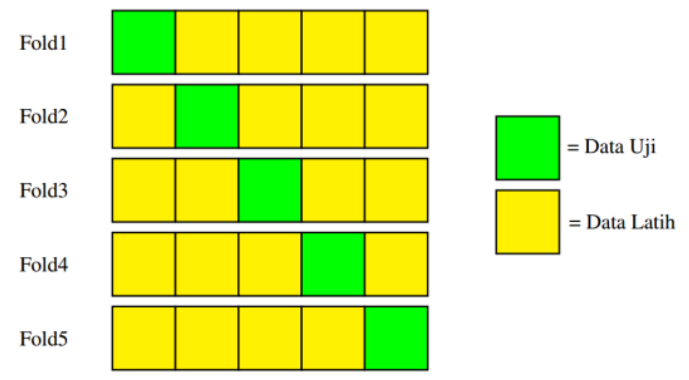

Gambar 9 5-Fold Cross Validation

Pengujian data dengan 5-Fold Cross Validation awalnya dilakukan dengan menggunakan $1 / 5(20 \%)$ bagian awal dari dataset sebagai data uji dan 4/5(80\%) bagian lainnya sebagai data latih dan seterusnya untuk Fold berikutnya, dengan data uji merupakan 1/5 bagian lainnya berurutan sesuai pada Gambar 9. Setelah proses tersebut akan digunakan confusion matrix untuk memperoleh akurasi, True Positive Rate (TPR) dan False Discovery Rate (FDR). 
Semua hasil akurasi dari masing-masing Fold dirata-ratakan sehingga diperoleh rata-rata akurasi yang merupakan hasil akhir dari pengujian sistem. Akurasi menunjukkan ketepatan sistem dalam melakukan klasifikasi, TPR menunjukkan seberapa berhasil sistem melakukan klasifikasi pada kelas yang sesuai dan FDR menunjukkan seberapa sering sistem melakukan kesalahan pada klasifikasi terhadap kelas yang ada.

\section{HASIL DAN PEMBAHASAN}

\subsection{Subjek Penelitian}

Subjek penelitian adalah delapan orang laki-laki berusia 20-25 tahun dengan kondisi penglihatan yang normal atau terkoreksi dan dalam kondisi sehat baik fisik maupun mental. Data berupa kode subjek dan usia dapat dilihat pada Tabel 2.

Tabel 2 Data subjek penelitian

\begin{tabular}{|l|l|l|}
\hline No. & Subjek & Usia \\
\hline 1. & Subjek 1 & 22 \\
2. & Subjek 2 & 22 \\
3. & Subjek 3 & 22 \\
4. & Subjek 4 & 22 \\
5. & Subjek 5 & 23 \\
6. & Subjek 6 & 20 \\
7. & Subjek 7 & 20 \\
8. & Subjek 8 & 20 \\
\hline
\end{tabular}

\subsection{Hasil Pra Pengolahan Data}

Analisis maupun klasifikasi pada penelitian ini digunakan sinyal pada jangkauan frekuensi 1-50 Hz, untuk itu dilakukan penapisan dengan tapis notch $50 \mathrm{~Hz}$ guna menghilangkan sinyal gangguan interferensi $50 \mathrm{~Hz}$ dan dilanjutkan dengan tapis lolos tengah 1$50 \mathrm{~Hz}$ guna memperoleh sinyal dengan frekuensi 1-50 Hz yang ditunjukkan pada Gambar 10.
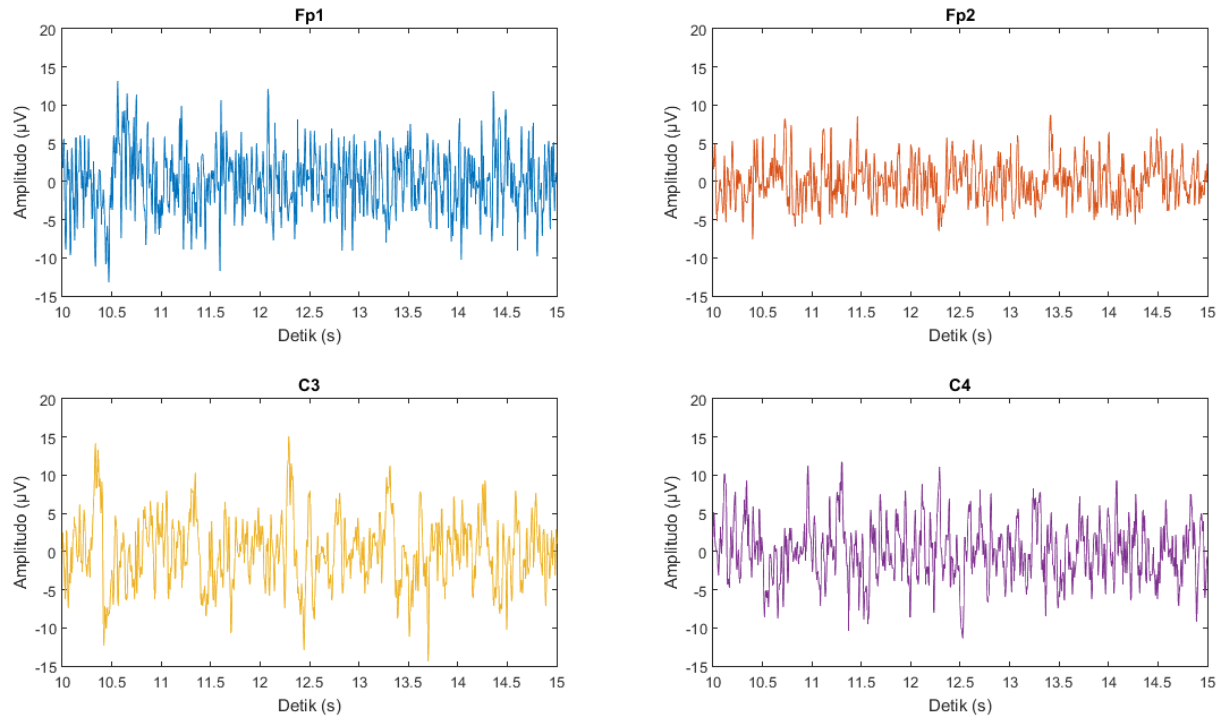

Gambar 10 Sinyal EEG hasil pra pengolahan

IJEIS Vol. 10, No. 2, October 2020 : 155 - 166 


\subsection{Hasil Ekstraksi Ciri}

Ekstraksi ciri dilakukan di ranah waktu dengan sinyal sepanjang satu detik. Setiap nilai ciri dihasilkan dari RMS satu detik data pada jangkauan frekuensi tertentu. Penelitian ini dihasilkan 32 ciri yang berasal dari penggunaan filter bank dengan delapan tapis lolos tengah yang masing-masing memiliki jangkauan lolos tengah yang berbeda dengan setiap tapis terdiri dari empat kanal. Hasil ektsraksi ciri RMS dari satu potong data dapat dilihat pada

Tabel 3.

Tabel 3 Ciri RMS

\begin{tabular}{|c|c|c|c|}
\hline \multirow{2}{*}{ No. } & \multicolumn{3}{|c|}{ Kelas } \\
\cline { 2 - 4 } & Kiri & Relaks & Kanan \\
\hline c1.1 & 0,721 & 0,663 & 1,014 \\
\hline c1.2 & 0,764 & 0,440 & 1,018 \\
\hline c1.3 & 1,161 & 0,833 & 0,359 \\
\hline c1.4 & 1,077 & 0,465 & 1,296 \\
\hline c2.1 & 1,104 & 0,934 & 0,554 \\
\hline c2.2 & 0,547 & 0,546 & 0,766 \\
\hline c2.3 & 0,352 & 0,509 & 0,659 \\
\hline c2.4 & 0,570 & 0,643 & 0,767 \\
\hline c3.1 & 0,527 & 0,755 & 0,994 \\
\hline c3.2 & 0,328 & 0,444 & 0,458 \\
\hline c3.3 & 0,302 & 0,533 & 0,724 \\
\hline c3.4 & 0,561 & 0,233 & 0,398 \\
\hline c4.1 & 0,569 & 0,988 & 0,854 \\
\hline c4.2 & 0,659 & 0,316 & 1,086 \\
\hline c4.3 & 0,805 & 0,442 & 0,658 \\
\hline c4.4 & 0,727 & 0,530 & 1,525 \\
\hline
\end{tabular}

\begin{tabular}{|c|c|c|c|}
\hline \multirow{2}{*}{ No. } & \multicolumn{3}{|c|}{ Kelas } \\
\cline { 2 - 4 } & Kiri & Relaks & Kanan \\
\hline c5.1 & 0,766 & 1,594 & 0,757 \\
\hline c5.2 & 0,386 & 0,562 & 0,629 \\
\hline c5.3 & 0,570 & 1,047 & 0,687 \\
\hline c5.4 & 0,683 & 0,406 & 0,690 \\
\hline c6.1 & 0,894 & 0,282 & 0,719 \\
\hline c6.2 & 0,319 & 0,278 & 0,409 \\
\hline c6.3 & 0,371 & 0,329 & 0,301 \\
\hline c6.4 & 0,374 & 0,478 & 0,347 \\
\hline c7.1 & 2,320 & 2,898 & 2,097 \\
\hline c7.2 & 1,756 & 1,596 & 1,794 \\
\hline c7.3 & 1,810 & 1,963 & 1,975 \\
\hline c7.4 & 1,840 & 1,675 & 2,202 \\
\hline c8.1 & 2,130 & 2,068 & 2,335 \\
\hline c8.2 & 1,140 & 1,168 & 1,231 \\
\hline c8.3 & 1,007 & 1,261 & 1,332 \\
\hline c8.4 & 1,387 & 1,022 & 1,341 \\
\hline
\end{tabular}

\subsection{Hasil Klasifikasi}

Setiap data masukan klasifikasi terdapat 32 ciri pada masing-masing kelas. Klasifikasi dengan 3 luaran terdapat 150 data dengan masing-masing kelas 50 data, begitu juga dengan klasifikasi dengan 2 luaran terdapat 100 data dengan masingmasing kelas 50 data. Berikut adalah tabel dari hasil klasifikasi beserta kelas keluarannya 
Tabel 4 Contoh hasil klasifikasi 3 luaran

\begin{tabular}{|ccc|c|}
\hline \multicolumn{3}{|c|}{ Luaran } & \multirow{2}{*}{ Kelas Keluaran } \\
\cline { 1 - 2 } luaran1 & luaran2 & luaran3 & \\
\hline 1,072 & $-0,853$ & 0,512 & Kiri \\
\hline 0,840 & $-0,142$ & $-0,139$ & Kiri \\
\hline 0,487 & $-0,551$ & 0,063 & Kiri \\
\hline 0,646 & 0,212 & 0,368 & Kiri \\
\hline 0,688 & 0,136 & 0,317 & Kiri \\
\hline 0,614 & 0,205 & 0,026 & Kiri \\
\hline 1,146 & $-0,433$ & 0,227 & Kiri \\
\hline 0,607 & $-0,010$ & 0,216 & Kiri \\
\hline 1,052 & $-0,026$ & $-0,390$ & Kiri \\
\hline$-0,330$ & 1,291 & 0,191 & Relaks \\
\hline 0,622 & $-0,326$ & 0,604 & Kiri \\
\hline 0,391 & $-0,282$ & 0,793 & Kanan \\
\hline 0,381 & 0,443 & 0,325 & Relaks \\
\hline 0,525 & $-0,218$ & 0,922 & Kanan \\
\hline 0,697 & 0,245 & 0,203 & Kiri \\
\hline
\end{tabular}

Tabel 5 Contoh klasifikasi 2 luaran

\begin{tabular}{|cc|c|}
\hline \multicolumn{2}{|c|}{ Luaran } & \multirow{2}{*}{ Kelas Keluaran } \\
\cline { 1 - 2 } luaran1 & luaran2 & \\
\hline 0,111 & 1,367 & Kanan \\
\hline 0,633 & 0,594 & Kiri \\
\hline 0,441 & 1,102 & Kanan \\
\hline 0,506 & 0,674 & Kanan \\
\hline 0,655 & 0,405 & Kiri \\
\hline 0,362 & 0,546 & Kanan \\
\hline 0,013 & 0,749 & Kanan \\
\hline 0,063 & 0,860 & Kanan \\
\hline 0,023 & 0,760 & Kanan \\
\hline 0,286 & 0,707 & Kanan \\
\hline
\end{tabular}

Cuplikan hasil klasifikasi pada Tabel 4 dan Tabel 5 berasal dari data uji. Hasil tersebut selanjutnya digunakan dalam pembuatan tabel confusion matrix untuk pengujian sistem BCI.

\subsection{Pembahasan}

Pengujian sistem dilakukan ke-8 subjek dengan masing-masing nilai merupakan ratarata akurasi dari 5-fold cross validation yang ditunjukkan pada Tabel 6 untuk sistem dengan klasifikasi 3 luaran dan Tabel 7 untuk sistem dengan klasifikasi 2 luaran

Tabel 6 Rata-rata akurasi setiap subjek untuk klasifikasi 3 luaran

IJEIS Vol. 10, No. 2, October 2020 : 155 - 166 


\begin{tabular}{|c|c|c|c|c|c|}
\hline \multirow{2}{*}{ Subjek } & \multicolumn{2}{|c|}{ Pelatihan (\%) } & \multicolumn{2}{c|}{ Pengujian (\%) } & \multirow{2}{*}{$\Sigma$} \\
\cline { 2 - 5 } & Sesi 1 & Sesi 2 & Sesi 1 & Sesi 2 & \\
\hline Subjek 1 & 76,12 & 74,97 & 72,12 & 67,93 & $\mathbf{7 2 , 7 8}$ \\
\hline Subjek 2 & 74,08 & 81,99 & 76,49 & 76,24 & $\mathbf{7 7 , 2 0}$ \\
\hline Subjek 3 & 65,22 & 59,01 & 74,69 & 74,92 & $\mathbf{6 8 , 4 6}$ \\
\hline Subjek 4 & 71,14 & 72,41 & 71,89 & 77,17 & $\mathbf{7 3 , 1 5}$ \\
\hline Subjek 5 & 73,38 & 72,31 & 76,06 & 69,99 & $\mathbf{7 2 , 9 3}$ \\
\hline Subjek 6 & 79,18 & 68,14 & 76,90 & $\mathbf{7 4 , 6 5}$ & $\mathbf{7 4 , 7 2}$ \\
\hline Subjek 7 & 73,50 & 68,71 & 73,18 & $\mathbf{7 1 , 0 3}$ & $\mathbf{7 1 , 6 0}$ \\
\hline Subjek 8 & $\mathbf{7 1 , 9 8}$ & 68,89 & 66,18 & 68,99 & $\mathbf{6 9 , 0 1}$ \\
\hline$\Sigma$ & $\mathbf{7 3 , 0 8}$ & $\mathbf{7 0 , 8 0}$ & $\mathbf{7 3 , 4 4}$ & $\mathbf{7 2 , 6 1}$ & $\mathbf{7 2 , 4 8}$ \\
\hline
\end{tabular}

Tabel 7 Rata-rata akurasi setiap subjek untuk klasifikasi 2 luaran

\begin{tabular}{|c|c|c|c|c|c|}
\hline \multirow{2}{*}{ Subjek } & \multicolumn{2}{|c|}{ Pelatihan (\%) } & \multicolumn{2}{c|}{ Pengujian (\%) } & \multirow{2}{*}{$\Sigma$} \\
\cline { 2 - 5 } & Sesi 1 & Sesi 2 & Sesi 1 & Sesi 2 & \\
\hline Subjek 1 & 83,16 & 67,94 & 81,81 & 80,59 & $\mathbf{7 8 , 3 7}$ \\
\hline Subjek 2 & 89,35 & 82,73 & 87,90 & 89,33 & $\mathbf{8 7 , 3 3}$ \\
\hline Subjek 3 & 66,65 & 55,45 & 81,39 & 80,69 & $\mathbf{7 1 , 0 5}$ \\
\hline Subjek 4 & 74,08 & 74,37 & 84,11 & 85,89 & $\mathbf{7 9 , 6 1}$ \\
\hline Subjek 5 & 80,69 & 70,92 & 85,60 & $\mathbf{7 9 , 5 8}$ & $\mathbf{7 9 , 2 0}$ \\
\hline Subjek 6 & 82,21 & 69,46 & 86,56 & 82,89 & $\mathbf{8 0 , 2 8}$ \\
\hline Subjek 7 & $\mathbf{7 6 , 5 2}$ & $\mathbf{7 1 , 6 6}$ & 83,49 & 82,19 & $\mathbf{7 8 , 4 7}$ \\
\hline Subjek 8 & 69,80 & $\mathbf{7 9 , 6 1}$ & $\mathbf{7 5 , 1 3}$ & $\mathbf{7 6 , 5 2}$ & $\mathbf{7 5 , 2 6}$ \\
\hline $\mathbf{\Sigma}$ & $\mathbf{7 7 , 8 1}$ & $\mathbf{7 1 , 5 2}$ & $\mathbf{8 3 , 2 5}$ & $\mathbf{8 2 , 2 1}$ & $\mathbf{7 8 , 7 0}$ \\
\hline
\end{tabular}

Sistem dengan klasifikasi 2 luaran dengan nilai akurasi rata-rata 78,70\% memiliki nilai lebih tinggi daripada klasifikasi 3 luaran yaitu 72,48\%. Hal ini sesuai dengan perancangan sistem BCI berbasis SSVEP bahwa pada pengembangan sistem yang dilakukan, perancangan stimulus berupa adanya kedipan frekuensi sangat berpengaruh pada proses klasifikasinya yang berujung pada hasil akhir pengujian sistem yaitu nilai akurasi dengan validasi 5-fold cross validation dan juga pada penelitian ini ditambahkan adanya perbedaan warna pada masingmasing stimulus.

Hasil pengujian sistem BCI berbasis SSVEP pada penelitian ini menunjukkan bahwa akurasi akhir yang dihasilkan oleh klasifikasi 2 luaran lebih tinggi daripada klasifikasi 3 luaran, hal ini menunjukkan bahwa pemberian stimulus SSVEP pada stimulus sangat mempengaruhi klasifikasi sistem BCI ini, pada klasifikasi 3 luaran terdapat kelas rileks yang tidak diberikan stimulus SSVEP berupa frekuensi kedipan. Klasifikasi 2 luaran untuk sesi 1 hasilnya lebih baik daripada sesi 2 ditunjukkan dari akurasi akhir serta TPR dan FDR pada masing-masing kelas. Sesi 1 membuktikkan bahwa subjek penelitian dapat lebih fokus ke objek stimulus yang muncul saja didukung dengan pemberian warna pada objek tersebut, sedangkan sesi 2 objek stimulusnya muncul secara bersamaan sehingga menyebabkan kurang fokus, dengan demikian hasil dari sesi 1 lebih baik daripada sesi 2 .

Penelitian ini dikembangkan sistem BCI berbasis SSVEP dengan durasi klasifikasi satu detik, empat kanal aktif serta peletakan kanal elektroda yang umum sesuai dengan The International 10-20 System, dengan demikian dapat mengatasi masalah pada penelitian sebelumnya yaitu penggunaan jendela waktu lima detik untuk klasifikasi, penggunaan delapan kanal aktif serta peletakan kanal elektroda di area yang khusus berupa area yang tidak berambut saja.

\section{KESIMPULAN}


Sistem Brain Computer Interface (BCI) yang telah dikembangkan adalah sistem BCI berbasis SSVEP dengan durasi klasifikasi satu detik, empat kanal aktif serta peletakan kanal elektroda sesuai The International 10-20 System. Objek stimulus berupa kedipan frekuensi ditambahkan dengan pemberian warna mampu menghasilkan akurasi akhir sebesar 78,70\% dengan True Positive Rate (TPR) 86,00\% dan False Discovery Rate (FDR) 23,21\%.

\section{SARAN}

Dibutuhkan seleksi ciri untuk meminimalisir jumlah ciri yang digunakan sehingga dapat mengoptimalisasi kecepatan komputasi proses klasifikasi dan Pengembangan lebih lanjut dengan implementasi pada sistem BCI berbasis SSVEP yang telah dikembangkan sehingga sistem dapat diterapkan secara online/realtime.

\section{DAFTAR PUSTAKA}

[1] S. Sanei and J. A. Chambers, EEG Signal Processing, vol. 1. 2007.

[2] G. Pfurtscheller et al., Brain-Computer Interfaces, vol. 53, no. 9. 2010.

[3] C. Yeou-Jinn, C. Shih-Chung, and W. Chung-Min, "Using Modular Neural Network to SSVEP-based BCI,” vol. 669, pp. 5-7, 2014.

[4] H. An, J. Kim, and S. Lee, "Design of an Asynchronous Brain-Computer Interface for Control of a Virtual Avatar," pp. 5-6, 2016.

[5] C. M. Wong, Q. Tang, J. Nuno Da Cruz, and F. Wan, "A multi-channel SSVEP-based BCI for computer games with analogue control," 2015 IEEE Int. Conf. Comput. Intell. Virtual Environ. Meas. Syst. Appl. CIVEMSA 2015, 2015.

[6] L. Yang and H. Leung, "An online BCI game based on the decoding of users ' attention to color stimulus," pp. 5267-5270, 2013.

[7] C. Atmaji and Z. Yudha Perwira, "Pengaruh Latar Belakang Warna pada Objek Gambar terhadap Hasil Ekstraksi Sinyal EEG 1," IJEIS, vol. 7, no. 2, pp. 161-172, 2017.

[8] A. Güneysu and H. L. Akin, "An SSVEP based BCI to control a humanoid robot by using portable EEG device," Conf. Proc. ... Annu. Int. Conf. IEEE Eng. Med. Biol. Soc. IEEE Eng. Med. Biol. Soc. Annu. Conf., vol. 2013, pp. 6905-6908, 2013.

[9] Yu-Te Wang et al., "Developing an online steady-state visual evoked potential-based brain-computer interface system using EarEEG.," Conf. Proc. ... Annu. Int. Conf. IEEE Eng. Med. Biol. Soc. IEEE Eng. Med. Biol. Soc. Annu. Conf., vol. 2015, pp. 2271-4, 2015.

[10] Y. Te Wang, M. Nakanishi, Y. Wang, C. S. Wei, C. K. Cheng, and T. P. Jung, "An Online Brain-Computer Interface Based on SSVEPs Measured from Non-Hair-Bearing Areas," IEEE Trans. Neural Syst. Rehabil. Eng., vol. 25, no. 1, pp. 11-18, 2017.

[11] J. Heaton, Introduction to Neural Networks for Java, Second., vol. 99. Heaton Research, Inc, 2008.

IJEIS Vol. 10, No. 2, October 2020 : 155 - 166 